\title{
Keterampilan Mahasiswa Prodi Pendidikan Fisika dalam mengembangkan media pembelajaran
}

\author{
Ino Angga Putra \\ Program Studi Pendidikan Fisika, Universitas KH. A. Wahab Hasbullah, Indonesia \\ Surat-e: inoanggaputra@unwaha.ac.id

\section{Suci Prihatiningtyas} \\ Program Studi Pendidikan Fisika, Universitas KH. A. Wahab Hasbullah, Indonesia \\ Surat-e: suci.ningtyas4317@gmail.com
}

\section{Hendrik Siswono}

Institut Keguruan dan Ilmu Pendidikan PGRI, Indonesia

Surat-e: hendriksiswono@gmail.com

\begin{abstract}
Abstrak. Tujuan penelitian ini adalah untuk mengetahui keterampilan mahasiswa dalam mengembangkan media pembelajaran fisika. Keterampilan pengembangan media pembelajaran perlu dimiliki mahasiswa pada kegiatan belajar mengajar di kelas. Metode penelitian yang digunakan adalah penelitian kualitatif deskriptif melalui kegiatan observasi atau pengamatan oleh 3 (tiga) observer. Sampel penelitian ini adalah mahasiswa semester V yang mengikuti mata kuliah Pengembangan Media Pembelajaran. Teknik sampling menggunakan purposive sampling. Pengumpulan data menggunakan instrumen penilaian perancangan media pembelajaran meliputi aspek ACTION dan VISUALS dengan menggunakan skala Likert. Hasil penelitian diperoleh keterampilan mahasiswa dalam mengembangkan media pembelajaran pada kategori sangat baik dengan skor 3,2. Keterampilan mahasiswa perlu ditingkatkan lagi pada aspek Organization (organisasi), Novelty (kebaruan), Accurate (dapat dipertanggungjawabkan), Legitimate (masuk akal), dan Structure (terstruktur). Keterampilan mahasiswa dalam mengembangkan media pembelajaran sudah baik namun perlu disesuaikan dengan kondisi dilapangan mencakup sarana prasrana di sekolah dan perkembangan IPTEK.
\end{abstract}

Kata kunci: Keterampilan, media pembelajaran, fisika.

\begin{abstract}
The purpose of this study was to determine student skills in developing physics learning media. Learning media development skills need to be had by students in teaching and learning activities in class. The research method used was descriptive qualitative research through observation or observation by 3 (three) observers. The sample of this research is the fifth-semester students who take the Learning Media Development course. The sampling technique uses purposive sampling. Collecting data using learning media design assessment instruments covering aspects of ACTION and VISUALS using a Likert scale. The results were obtained by students' skills in developing learning media in the excellent category with a score of 3.2. Students' skills need to be further improved in the aspects of Organization, Novelty (novelty), Accurate (can be accounted for), Legitimate (reasonable), and Structure (structured). Students' skills in developing instructional media are good but need to be adjusted to the field's conditions, including infrastructure in schools and the development of science and technology.
\end{abstract}

Keywords: Skill, learning media, physics. 


\section{Pendahuluan}

Perkembangan ilmu pengetahuan dan teknologi (IPTEK) semakin pesat dan modern menjadi dasar peningkatan kemampuan sumber daya manusia. Perkembangan IPTEK dibidang pendidikan dapat membantu menjawab tantangan tentang pengaruh teknologi dalam mengkonstruksi sistem pendidikan dan sejalan dengan ilmu pengetahuan atau materi pembelajaran [1], [2]. Kemampuan yang perlu dimiliki salah satunya keterampilan untuk berinovasi dan kreatif dalam menciptakan sesuatu. Proses pembelajaran menjadi salah satu dampak perkembangan IPTEK sehingga berimbas pada keterampilan pendidik mengelola pembelajaran tersebut. Seorang pendidik harus dapat memanfaatkan IPTEK yaitu TIK dalam pembelajaran sebagai bentuk pengembangan diri [3]. Pemanfaatan TIK akan memudahkan kerja pendidik dimana selain pemberi informasi atau pesan juga sebagai fasilitator peserta didik menemukan suatu ilmu pengetahuan [4]. Selain itu, pendidik memiliki peran yang sangat menentukan terhadap kualitas pendidikan melalui proses pembelajaran.

Mendukung peningkatan kualitas pendidikan pada proses pembelajaran maka pendidik perlu memanfaatkan IPTEK sebagai media pembelajaran. Media pembelajaran merupakan komponen penting untuk menyampaikan suatu pesan atau informasi dalam suatu materi pembelajaran [5], [6]. Media pembelajaran menjadi perantara komunikasi antara pendidik dengan peserta didik maupun peserta didik dengan peserta didik lainnya. Oleh karena itu, mahasiswa sebagai calon pendidik perlu mengetahui cara menentukan dan merancang suatu media pembelajaran yang tepat agar capaian pembelajaran yang disusun akan tercapai.

Kenyataan di lapangan pengembangan suatu media pembelajaran mengalami kendala. Beberapa faktor yang mempengaruhi pengembangan media pembelajaran menurut Rumidjan, dkk. yaitu kurang terampilnya seorang pendidik untuk merancang suatu media pembelajaran, dan kurangnya sarana prasarana menjadi alasan penting juga sehingga pembelajaran menjadi tidak aktif [7]. Selain itu, terbatasnya waktu untuk membuat persiapan pembelajaran dan tidak tersedianya biaya pembuatan media pembelajaran [8]. Menurut Pebrianto menyatakan bahwa permasalahan tersebut tidak perlu terjadi jika pendidik atau mahasiswa calon pendidik telah memiliki pengetahuan dan keterampilan dalam mengembangkan media pembelajaran [8].

Keterampilan mengembangkan media pembelajaran perlu dimiliki oleh mahasiswa calon pendidik maupun pendidik. Keterampilan ini akan membantu berjalannya proses pembelajaran khususnya pada materi Fisika yang bersifat abstrak agar menjadi lebih konkrit [2]. Mahasiswa calon pendidik perlu melakukan perencanaan penggunaan media pembelajaran dengan menyesuaikan materi pembelajaran. Selain itu, perlu juga mengacu pada permasalahan kurangnya pengetahuan dan ketrampilan mahasiswa calon pendidik atau guru (pendidik) dengan melihat kondisi di lapangan agar dapat mencapai tujuan pembelajaran.

Hasil pengembangan media pembelajaran yang tepat akan memberikan kontribusi yang baik untuk peserta didik. Berikut beberapa hasil penelitian terkait dampak media pembelajaran pada proses pembelajaran. Media pembelajaran Flipbook dapat meningkatkan pemahaman konsep Fisika dan keterampilan proses sains mahasiswa [9]. Media alat peraga sederhana berbasis pendekatan sains teknologi masyarakat sangat efektif digunakan mendukung hasil belajar mahasiswa dengan nilai rata-rata 82 [10]. Nurrita menyatakan bahwa media pembelajaran memudahkan proses belajar mengajar dan dapat menarik perhatian peserta didik untuk terlibat didalam pembelajaran [11]. Media pembelajaran juga dapat meningkatkan hasil belajar dimana peserta didik aktif mengikuti dan terlibat selama pembelajaran berlangsung [11]. Pembelajaran menjadi lebih efektif dan efeisien sehingga capaian pembelajaran tercapai.

Berdasarkan penjabaran diatas, tujuan penelitian ini adalah untuk mengetahui keterampilan mahasiswa dalam mengembangkan suatu media pembelajaran pada materi Fisika selama perkuliahan Mata Kuliah Pengembangan Media Pembelajaran. Keterampilan dalam mengembangkan media pembelajaran perlu dimiliki oleh mahasiswa ataupun guru sebagai bentuk peningkatan keterampilan pemanfaatan teknologi dikehidupan sehari-hari. Selain itu, sebagai upaya peningkatan kualitas mutu pembelajaran yang efisien dan efektif.

\section{Metode Penelitian}

Penelitian ini merupakan jenis penelitian kualitatif deskriptif. Subjek penelitian adalah mahasiswa Prodi Pendidikan Fisika semester V sejumlah 10 mahasiswa yang sedang menempuh Mata Kuliah Pengembangan Media Pembelajaran Fisika. Sampel penelitian diambil menggunakan teknik purposive sampling dikarenakan 
mata kuliah Pengembangan Media Pembelajaran Fisika hanya diikuti oleh 10 mahasiswa pada semester V. Instrumen penelitian menggunakan angket survey keterampilan mahasiswa dalam mengembangkan media pembelajaran materi Fisika yang memuat 2 (dua) kriteria yaitu ACTION (Acces, Cost, Technology, Interactivity, Organization, \& Novelty) dan VISUALS (Visible, Interesting, Simple, Useful, Accurate, Legitimate, \& Structure) [5] pada Tabel 1 dan Tabel 2. Instrumen penelitian menggunakan skala Likert dengan nilai 1 = tidak baik, $2=$ kurang baik, $3=$ baik, dan $4=$ sangat baik dan kriteria penilaian pada Tabel 3. Pengumpulan data dilakukan dengan kegiatan survey atau observasi pada proses perkuliahan dalam rentang waktu 2 bulan yaitu bulan November dan Desember. Pengumpulan data dilakukan oleh 3 observer. Analisa data hasil survey atau observasi dilakukan menggunakan teknik statistik deskriptif dengan mengkaji hasil penelitian yang mencakup 2 (dua) kriteria ACTION dan VISUALS.

Tabel 1. Kriteria Penilaian Keterampilan Pengembangan Media Pembelajaran pada ACTION

\begin{tabular}{|c|c|}
\hline Kriteria & Keterangan \\
\hline Acces & $\begin{array}{l}\text { Mudah dicari, tersedia, dan dapat } \\
\text { dimanfaatkan }\end{array}$ \\
\hline Cost & Pembiayaan dapat dijangkau \\
\hline Technology & $\begin{array}{l}\text { Mudah digunakan dan tersedia } \\
\text { teknologi }\end{array}$ \\
\hline Interactivity & $\begin{array}{l}\text { Memunculkan komunikasi } 2 \text { (dua } \\
\text { arah) atau interaktivitas }\end{array}$ \\
\hline Organization & $\begin{array}{l}\text { Mendapat dukung dari organisasi } \\
\text { atau pihak sekolah }\end{array}$ \\
\hline Novelty & Pertimbangan kebaruan dari media \\
\hline
\end{tabular}

Tabel 2. Kriteria Penilaian Keterampilan Pengembangan Media Pembelajaran pada VISUALS

\begin{tabular}{ll}
\hline \multicolumn{1}{c}{ Kriteria } & \multicolumn{1}{c}{ Keterangan } \\
\hline Visible & Mudah dilihat \\
Interesting & Menarik \\
Simple & Sederhana \\
Useful & Isinya bermanfaat/berguna \\
Accurate & Benar (dapat \\
& dipertanggungjawabkan) \\
Legitimate & Masuk akal/sah \\
Structure & Terstruktur/tersusun dengan baik \\
& dan rapi \\
\hline
\end{tabular}

Tabel 3. Skor Penilaian pada Instrumen

\begin{tabular}{ll}
\hline \multicolumn{1}{c}{ Rentang Nilai } & \multicolumn{1}{c}{ Keterangan } \\
\hline $3,1-4,0$ & Sangat Baik/Sesuai \\
$2,1-3,0$ & Baik/Sesuai \\
$1,1-2,0$ & Kurang Baik/Sesuai \\
$0,0-1,0$ & Tidak Baik/Sesuai \\
\hline
\end{tabular}

\section{Hasil Penelitian dan Pembahasan}

Data yang diperoleh pada penelitian ini disajikan pada Tabel 4 dan Tabel 5 melalui kegiatan observasi kegiatan mahasiswa pada perkuliahan Mata Kuliah Pengembangan Media Pembelajaran. Data penelitian mencakup keterampilan mahasiswa dalam mengembangkan media pembelajaran yaitu ACTION dan VISUALS. Data penelitian ini menunjukkan bahwa keterampilan mahasiswa dalam mengembangkan media pembelajaran pada kategori sangat baik dengan skor rata-rata sebesar 3,2 
Tabel 4. Skor Rata-Rata Keterampilan Mahasiswa pada Kriteria ACTION

\begin{tabular}{clcl}
\hline No & \multicolumn{1}{c}{ Aspek } & Skor Rata-Rata & \multicolumn{1}{c}{ Keterangan } \\
\hline 1 & Acces & 3,6 & Sangat Baik/Sesuai \\
2 & Cost & 3,6 & Sangat Baik/Sesuai \\
3 & Technology & 3,1 & Sangat Baik/Sesuai \\
4 & Interactivity & 3,1 & Sangat Baik/Sesuai \\
5 & Organization & 2,8 & Baik/Sesuai \\
6 & Novelty & 3,1 & Sangat Baik/Sesuai \\
\hline
\end{tabular}

Tabel 2 menunjukkan pada pengembangan media pembelajaran dengan kriteria ACTION dimana pengembangan media perlu memperhatikan kegunaan atau operasional dari media tersebut. Pada aspek pertama yaitu Acces dimana menilai kemudahan media pembelajaran untuk diakses atau digunakan. Aspek Acces memiliki nilai 3,6 dimana keterampilan mahasiswa kategori sangat baik dalam merancang media pembelajaran sehingga memiliki kemudahan dalam penggunaan atau akses operasionalnya. Media pembelajaran yang sering dibuat oleh mahasiswa adalah media 2 Dimensi dan 3 Dimensi. Kemudahan akses ini dikarenakan mahasiswa merancang medianya menggunakan peralatan dan bahan yang mudah ditemui dilingkungan sekitar baik oleh guru maupun peserta didik. Kemudahan akses menjadi dasar kebutuhan peserta didik yang beragam sehingga peserta didik nyaman menggunakan media pembelajaran yang ada. Salah satu media pembelajaran yang dikembangkan oleh mahasiswa dengan unsur media yang mudah diakses yaitu Gambar Model Atom, Animasi, dan Alat Peraga Kesetimbangan (Gambar 1).

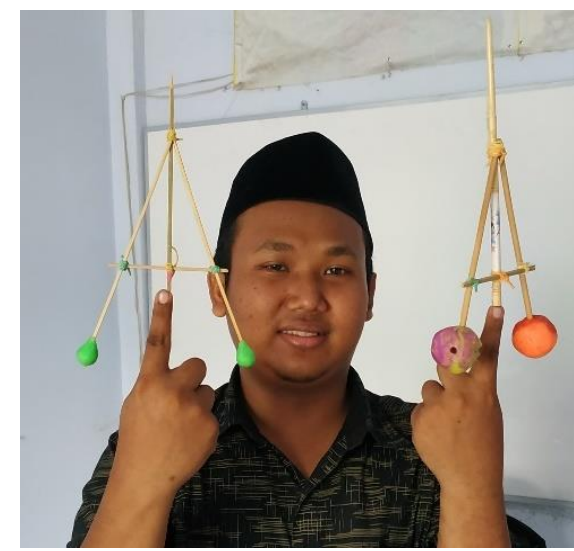

Gambar 1. Alat peraga kesetimbangan

Aspek Cost menunjukkan pada kategori sangat baik dengan skor 3,6. Media pembelajaran yang dibuat mahasiswa memang menggunakan peralatan dan bahan yang mudah diperoleh mengacu pada aspek Acces sehingga biaya yang dikeluarkan relatif kecil. Hal ini memang perlu dimiliki oleh para mahasiswa calon guru agar lebih kreatif dengan memanfaatkan alam sekitar dalam melaksanakan pembelajaran apabil kondisi lembaga pendidikannya kurang mendukung atau memadai. Hal ini dibuktikan oleh hasil media pembelajaran yang sudah dibuat, salah satunya yaitu media pembiasan cahaya dengan menggunakan gelas berisi air dan pensil/bolpoint.

Aspek Technology menunjukkan pada kategori sangat baik dengan skor 3,1. Rata-rata media pembelajaran yang telah dibuat memang lebih pada media 2 Dimensi dan 3 Dimensi yang sederhana. Hal ini memang perlu diperhatikan bahwa keterampilan mahasiswa perlu dilatih lagi dalam mengembangkan suatu media pembelajaran yang sinergi dengan perkembangan zaman. Media pembelajaran yang dibuat memang telah didasarkan pada kebutuhan materi dan waktu yang dibutuhkan untuk membuat. Selain itu, pengembangan media ini didasarkan pada fasilitas yang ada di suatu lembaga pendidikan. Salah satu contoh pengembangan media pembelajaran pada aspek ini adalah media 3 dimensi berupa alat peraga gerak bandul sederhana (Gambar 2). 


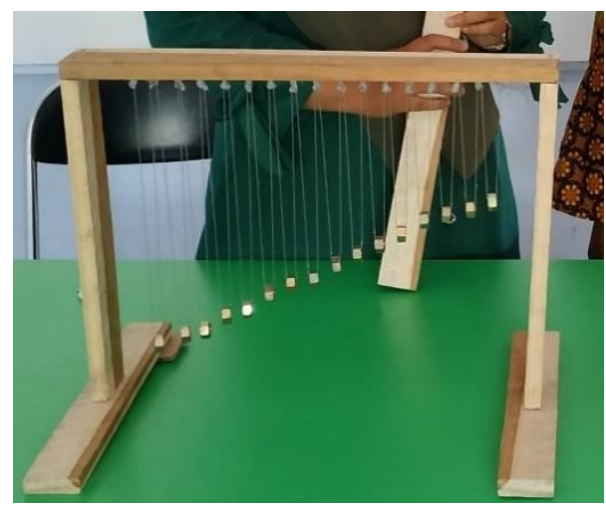

Gambar 2. Media 3 dimensi berupa alat peraga gerak bandul sederhana

Aspek Interactivity menunjukkan pada kategori sangat baik dengan skor 3,1. Media pembelajaran yang telah dibuat oleh mahasiswa memang cenderung mengarah kemudahan dalam hal penggunaan atau pengoperasian. Hasil observasi menunjukkan bahwa media pembelajaran yang dikembangkan telah menyesuaikan dengan materi yang disampaikan sehingga memudahkan pendidik dan peserta didik untuk berinteraksi. Hal ini akan memudahkan proses pembelajaran berlangsung dengan adanya interaksi antara guru dengan siswa dan siswa dengan siswa lainnya melalui penggunaan media pembelajaran. Media pembelajaran yang dikembangkan dengan memuat aspek interactivity salah satunya yaitu Bandul Sederhana.

Aspek Organization menunjukkan pada kategori baik dengan skor 2,8. Media pembelajaran yang dikembangkan mahasiswa memang perlu adanya dukungan dari pihak sekolah atau lembaga pendidikan sebagai penyelenggara pendidikan. Hal ini perlu diperhatikan bagi mahasiswa agar dapat menyesuaikan kondisi dilapangan baik yang berkaitan dengan sarana prasarana maupun keuangan yang ada di sekolah atau lembag pendidikan.

Aspek Novelty menunjukkan pada kategori sangat baik dengan skor 3,1. Media pembelajaran yang dikembangkan oleh mahasiswa harus memiliki nilai kebaruan dengan menyesuaikan perkembangan zaman. Media yang dikembangkan memang masih menggunakan alat dan bahan yang sederhana. Namun, mengacu pada aspek Technology memang beberapa ada yang mengembangkan dengan nilai kebaruan yang sangat baik. Hal ini memang mengacu pada sekolah atau lembaga pendidikan yang dipilih berdasarkan fasilitas yang ada didalamnya.

Tabel 5. Skor Rata-Rata Keterampilan Mahasiswa pada Kriteria VISUALS

\begin{tabular}{clcl}
\hline No & Aspek & Skor Rata-Rata & \multicolumn{1}{c}{ Keterangan } \\
\hline 1 & Visible & 3,5 & Sangat Baik/Sesuai \\
2 & Interesting & 3,1 & Sangat Baik/Sesuai \\
3 & Simple & 3,7 & Sangat Baik/Sesuai \\
4 & Useful & 3,6 & Sangat Baik/Sesuai \\
5 & Accurate & 3,0 & Baik/Sesuai \\
6 & Legitimate & 2,9 & Baik/Sesuai \\
7 & Structure & 2,9 & Baik/Sesuai \\
\hline
\end{tabular}

Tabel 3 menunjukkan pada pengembangan media pembelajaran dengan kriteria VISUALS dimana pengembangan media perlu memperhatikan tampilan atau sajian dari media tersebut. Pada aspek pertama yaitu Visible menunjukkan pada kategori sangat baik dengan skor 3,5 dimana keterampilan mahasiswa kategori sangat baik dalam merancang media pembelajaran. Media pembelajaran yang dikembangkan mudah dilihat dan mudah digunakan. Kemudahan dilihat akan membantu peserta didik untuk menggunakannya dan memahami suatu konsep/materi. Media pembelajaran perlu didesain agar mudah dilihat oleh peserta didik dalam arti media pembelajaran tidak boleh terlalu kecil atau dapat mempersulit peserta didik untuk belajar seperti media pembelajaran pada Gambar 3. 


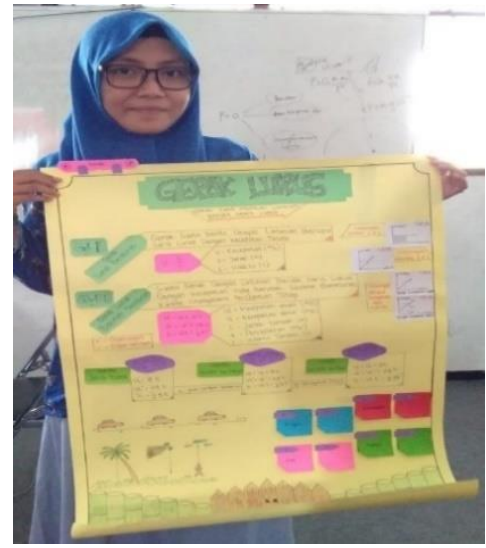

Gambar 3. Media 2 dimensi peta konsep materi gerak lurus

Aspek Interesting menunjukkan pada kategori sangat baik dengan skor 3,1. Media pembelajaran mahasiswa memang sangat baik namun perlu diperbaiki dalam hal tampilan dan sajiannya dengan menyesuaikan isi materi pembelajaran. Mahasiswa perlu mengembangkan keterampilan dalam mendesain medianya agar terlihat menarik dan enak dilihat. Media pembelajaran yang dikembangkan harus memiliki daya tarik tersendiri atau ciri khas tertentu. Aspek ini sangat berpengaruh pada penggunaan media pembelajaran untuk menarik perhatian peserta didik agar dapat fokus pada materi yang disampaikan. Oleh karena itu, media pembelajaran harus menyajikan tampilan yang unik dan menarik minat peserta didik dengan menyesuaikan materi pembelajaran.

Aspek Simple menunjukkan pada kategori sangat baik dengan skor 3,7. Mahasiswa dapat mengembangkan media pembelajaran dengan menggunakan peralatan dan bahan yang mudah diperoleh baik guru maupun peserta didik. Media pembelajaran yang dikembangkan berupa 2 dimensi maupun 3 dimensi serta media pembelajaran yang diproyeksikan maupun tidak. Media pembelajaran yang baik adalah media pembelajaran yang dapat digunakan dan mudah didapatkan atau dibuat. Oleh karena itu, media pembelajaran perlu didesain dengan memperhitungkan kondisi di lapangan yaitu karakteristik peserta didik dan sarana prasarana di sekolah atau lembaga pendidikan.

Aspek Useful menunjukkan pada kategori sangat baik dengan skor 3,6. Mahasiswa dapat mengembangkan media pembelajaran dengan mengacu pada aspek Simple dimana media dapat digunakan atau dapat dimanfaatkan. Media yang telah dikembangkan oleh mahasiswa antara lain alat peraga Hukum Pascal (Gambar 4). Media pembelajaran yang dikembangkan perlu memiliki kebermanfaatan dalam proses pembelajaran agar dapat digunakan oleh guru maupun peserta didik. Mahasiswa atau calon guru perlu mengasah keterampilan dalam mengembangkan media pembelajaran dengan memanfaatkan alam sekitar.

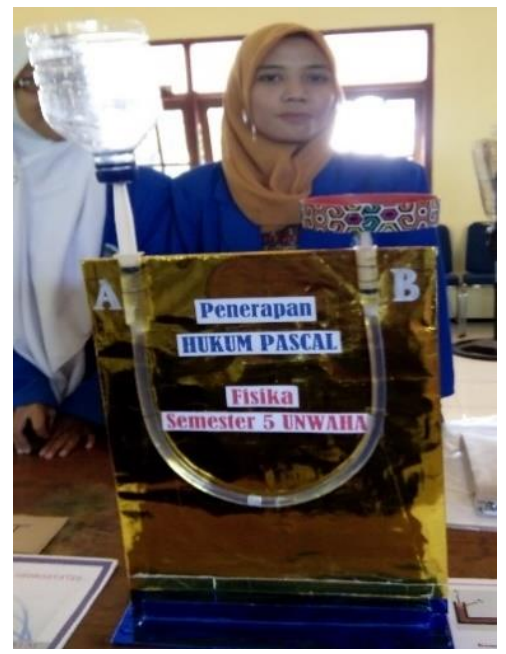

Gambar 4. Alat peraga Hukum Pascal 
Aspek Accurate menunjukkan pada kategori baik dengan skor 3,0. Media pembelajaran yang dikembangkan oleh mahasiswa masih perlu dikaji lagi terkait kebenaran dan dapat dipertanggungjawabkan medianya. Beberapa mahasiswa ada yang menggunakan media orang lain tanpa dilakukan pengeditan. Hal ini memang perlu diperhatikan oleh mahasiswa calon guru agar lebih kreatif dan inovatif serta bijak dalam merancang suatu media pembelajaran. Media pembelajaran yang dikembangkan tidak perlu bagus atau.

Aspek Legitimate menunjukkan pada kategori baik dengan skor 2,9. Media pembelajaran yang telah dikembangkan mahasiswa memang masuk akal atau sah untuk digunakan. Namun perlu diperhatikan dimana media pembelajaran yang ada perlu disesuaikan dengan materi atau capaian pembelajaran yang ada pada perangkat pembelajaran seperti silabus atau rencana pelaksanaan pembelajaran. Selain itu, media pembelajaran mahasiswa perlu didesain dengan sebaik-baiknya. Hal ini juga berkaitan dengan aspek Structure yang menunjukkan pada kategori baik dengan skor 2,9. Media pembelajaran yang dibuat mahasiswa sudah terstruktur dan dirancang sesuai jenis media dan materi pembelajaran. Oleh karena itu, media pembelajaran sebaiknya dirancang dan disusun secara sistematis dan terstruktur berdasarkan materi pembelajaran dan capaian pembelajaran.

Media pembelajaran memiliki peran yang sangat penting didalam proses pembelajaran.Media pembelajaran merupakan suatu alat perantara komunikasi antara pendidik dan peserta didik. Media pembelajaran dapat membantu peserta didik untuk menangkap pesan dan menyalurkan pesan kedalam perasaan dan kemauan pada proses pembelajaran. Nurseto dan Sanjaya menyatakan bahwa media pembelajaran merupakan bentuk wahana belajar untuk menyampaikan pesan atau informasi belajar [5], [6]. Media pembelajaran merupakan sumber belajar untuk membantu guru dan menambah wawasan peserta didik [11].

Pentingnya media pembelajaran dalam proses pembelajaran menjadi dasar mahasiswa calon pendidik dan pendidik untuk memiliki keterampilan mengembangan media pembelajaran. Keterampilan mengembangkan media pembelajaran mahasiswa dengan mengacu pada kriteria ACTION [12] dan VISUALS [5].

Media pembelajaran yang dikembangan dengan terstruktur maka akan berdampak pada proses pembelajaran. Beberapa hasil penelitian telah menunjukkan hal tersebut. Penggunaan media pembelajaran berbasis multimedia dapat mendukung peserta didik lebih fokus pada materi sehingga meningkatkan pemahaman dan interaksi peserta didik [13]. Media pembelajaran berbasis digital dapat meningkatkan pemahaman konsep [9]. Media pembelajaran berbasis komputer efektif pada proses pembelajaran dan meningkatkan keterampilan dan interaksi peserta didik [1]. Nasir, dkk. menyatakan bahwa media pembelajaran berbasis animasi dapat memotivasi peserta didik dalam belajar [15]. Elisa dan Wiratmaja menambahkan bahwa penggunaan media pembelajaran berupa Augmented Reality dapat meningkatkan keterampilan 4C mahasiswa [15]. Selain itu, media pembelajaran dalam bentuk alat peraga dapat meningkatkan hasil belajar peserta didik dan efektif pada proses pembelajaran [10].

\section{Kesimpulan}

Penelitian ini dilaksanakan untuk mengetahui keterampilan mahasiswa merancang suatu media pembelajaran pada materi Fisika. Rata-rata keterampilan mahasiswa menunjukkan nilai yang sangat baik dengan skor 3,2. Penelitian ini menjadi dasar untuk peningkatan kompetensi dan keterampilan mahasiswa agar nantinya dapat mengembangkan media pembelajaran secara mandiri dan sesuai kondisi dilapangan. Namun perlu diperhatikan pada beberapa aspek untuk ditingkatkan lebih baik lagi yaitu aspek Organization, Novelty, Accurate, Legitimate, dan Structure. Media pembelajaran yang dikembangkan juga perlu ditingkatkan dengan menyesuaikan perkembangan zaman yang semakin modern dan canggih yaitu penggunaan teknologi informasi dan komputer (TIK) dan kondisi sarana prasrana dilapangan yaitu sekolah. Kendala yang dihadapi pada penelitian ini adalah karena media yang dinilai sangat beragam sehingga penilai membutuhkan waktu yang lumayan lama dalam menilai. Penelitian ini dapat menjadi referensi untuk penelitian yang serupa atau lanjutan dengan memperhatikan beberapa hal meliputi penilaian rancangan media pembelajaran perlu menggunakan penilaian dari pendidik atau melibatkan lembaga pendidikan, kesiapan mahasiswa terkait kesesuaian media pembelajaran dengan materi pembelajaran, dan perlu diujicobakan kepada peserta didik sesuai materi yang disampaikan. 


\section{Ucapan Terimakasih}

Terima kasih peneliti sampaikan kepada pihak-pihak yang turut mendukung pelaksanaan penelitian ini yaitu sivitas akademika Program Studi Pendidikan Fisika Universitas KH. A. Wahab Hasbullah, Lembaga Penelitian dan Pengabdian pada Masyarakat (LPPM) Universitas KH. A. Wahab Hasbullah, dan keluarga peneliti.

\section{Kepustakaan}

[1] A. A. Sakat, M. Z. Mohd Zin, R. Muhamad, A. Ahmad, N. A. Ahmad, and M. A. Kasmo, "Educational technology media method in teaching and learning progress," Am. J. Appl. Sci., vol. 9, no. 6, pp. 874-878, 2012, doi: 10.3844/ajassp.2012.874.878.

[2] M. Afriyanti, S. Sodikin, and A. Jadmiko, "Pengembangan Media Pembelajaran Fisika Menggunakan Macromedia Flash Pro 8 Materi Gerak Lurus,” Indones. J. Sci. Math. Educ., vol. 1, no. 3, pp. 197-206, 2018, doi: 10.24042/ijsme.v1i3.3594.

[3] Sumarni and Pitriani, "Profil Keterampilan Membangkan Media Pembelajaran," in Prosiding Seminar Nasional Etnomatnesia, 2011, no. 2, pp. 910-918.

[4] E. Wassan, A. Hashim, and H. A. Hashim, "Selection of Appropriate Media and Technology for Distance Education," Int. J. Sci. Res., vol. 4, no. 11, pp. 1209-1216, 2015, doi: 10.21275/v4i11.nov151151.

[5] T. Nurseto, "Membuat Media Pembelajaran yang Menarik," J. Ekon. dan Pendidik., vol. 8, no. 1, pp. 19-35, 2012, doi: 10.21831/jep.v8i1.706.

[6] W. Sanjaya, "Strategi Pembelajaran Berorientasi Standar Proses Pendidikan,” System. 2010.

[7] Rumidjan, Sumanto, Sukamti, and S. Sugiharti, "Pelatihan Pembuatan Media Pembelajaran Untuk Meningkatkan Kualitas Pembelajaran Bagi Guru Sekolah Dasar,” Abdimas Pedagog., vol. 1, no. 1, pp. 77-81, 2017.

[8] F. Pebrianti, "Kemampuan Guru dalam Membuat Media Pembelajaran Sederhana Kemampuan Guru dalam Membuat Media Pembelajaran Sederhana," in Prosiding Seminar Nasional Bulan Bahasa (Semiba), 2019, no. December, pp. 93-98.

[9] I. A. Putra and E. Sujarwanto, "Rekonstruksi Bahan Ajar Multimedia Interaktif pada Mata Kuliah Alat Ukur dan Pengukuran dengan Pendekatan Behavioristik terhadap Penguasaan Konsep Peserta Didik," Pros. Semin. Nas. Pendidik. IPA, vol. 2, pp. 196-205, 2017.

[10] S. Prihatiningtyas and I. A. Putra, "Efektivitas penggunaan alat peraga sederhana berbasis pendekatan sains teknologi masyarakat pada materi fluida statis," J. Ris. dan Kaji. Pendidik. Fis., vol. 5, no. 2, p. 102, 2018, doi: 10.12928/jrkpf.v5i2.10988.

[11] H. Dalman, Menulis Karya Ilmiah, vol. 1, no. 1. 2012.

[12] W. Sanjaya, "Perencanaan dan Desain Sistem Pembelajaran Edisi Pertama," Prenada Media Group. 2012.

[13] M. Nazir, A. Rizvi, and R. Pujeri, "Skill development in multimedia based learning environment in higher education: An operational model," Int. J. Inf., vol. 2, no. 11, 2012.

[14] M. Nasir, R. B. Prastowo, and R. Riwayani, "Design and Development of Physics Learning Media of Three Dimensional Animation Using Blender Applications on Atomic Core Material," J. Educ. Sci., vol. 2, no. 2, p. 23, 2018, doi: 10.31258/jes.2.2.p.23-32.

[15] E. Elisa and Ig. Wiratmaja, "Augmented reality: Analisis Pengembangan Media Pembelajaran Kimia untuk Meningkatkan Keterampilan 4C Mahasiswa,” J. Indones. Soc. Integr. Chem., vol. 11, no. 2, pp. 73-81, 2019, doi: $10.22437 /$ jisic.v11i2.8124. 